Pharmaceutical Research Center, Meiji Seika Kaisha Ltd, Morooka, Kohoku-ku, Yokohama 222-8567, Japan

\section{Proposal to transfer Actinomadura carminata to a new subspecies of the genus Nonomuraea as Nonomuraea roseoviolacea subsp. carminata comb. nov.}

\author{
Yasuhiro Gyobu and Shinji Miyadoh
}

Author for correspondence: Shinji Miyadoh. Tel: +81 45545 3131. Fax: +81 455439771. e-mail: shinji_miyado@meiji.co.jp

\begin{abstract}
An anthracycline-producing actinomycete (strain SF2303) was compared with two other anthracycline producers, Actinomadura carminata IFO $15903^{\top}$ and Nonomuraea roseoviolacea IFO $1^{14098}{ }^{\top}$, using morphological, physiological, chemotaxonomic and molecular-genetic criteria. The morphological and cultural characteristics of these three strains are similar. The physiological properties of strain SF2303 and $N$. roseoviolacea IFO $14098^{\top}$ are very similar, but are different from those of $A$. carminata IFO $15903^{\top}$ in the utilization of some sugars and the reduction of nitrate. Their chemotaxonomic properties [cell wall chemotype, IIIB; major menaquinone, MK-9 (III, VIII-H H $_{4}$; phospholipid type, PIV; cellular fatty acids 10M-17:0/17:1 and iso-16:0 as major components and 2-hydroxy fatty acids as minor components; mycolic acid, absent] were identical and indicated that these three strains belong to the family Streptosporangiaceae. On the basis of 16S rDNA sequences and phylogenetic analysis, they were all included in the cluster formed by species of Nonomuraea. The levels of DNA relatedness between strain SF2303 and $\boldsymbol{N}$. roseoviolacea IFO $14098^{\top}$ ranged from 71 to $78 \%$; however, the levels of relatedness between the two strains and $A$. carminata IFO $15903^{\top}$ were lower (49-60\%). Therefore, strain SF2303 was identified as a member of the species $N$. roseoviolacea and it is proposed that Actinomadura carminata Gauze et al. 1973 should be transferred to a new subspecies of the genus Nonomuraea Zhang et al. 1998 as $N$. roseoviolacea subsp. carminata comb. nov.
\end{abstract}

Keywords: Actinomadura carminata, family Streptosporangiaceae, anthracyclineproducing actinomycetes

\section{INTRODUCTION}

In our screening programme for new anti-tumour antibiotics, we isolated an anthracycline-producing actinomycete, strain SF2303. For identification, it was compared with two anthracycline-producing organisms, Actinomadura carminata IFO $15903^{\mathrm{T}}$ and Nonomuraea roseoviolacea IFO $14098^{\mathrm{T}}$. Morphological, physiological, chemotaxonomic (including the HPLC patterns of secondary metabolites) and

The GenBank/EMBL/DDBJ accession numbers for the 16S rDNA sequences described in this work are AB039960 (strain SF2303), AB039961 (Actinomadura carminata IFO $15903^{\mathrm{T}}$ ) and AB039959 (Nonomuraea roseoviolacea IFO $14098^{\top}$ ). molecular-genetic (16S rDNA sequence analysis and DNA-DNA hybridization) criteria were used.

Taxonomic reviews of the genera of wall-chemotypeIII sporoactinomycetes such as Actinomadura, Microbispora, Microtetraspora, Nocardiopsis and Nonomuraea have been carried out since the 1980s (Fischer et al., 1983; Athalye et al., 1984; Poschner et al., 1985; Miyadoh et al., 1989, 1990; Grund \& Kroppenstedt, 1989). Kroppenstedt et al. (1990) revised the genera Actinomadura and Microtetraspora by using chemotaxonomic and molecular-genetic techniques and proposed to transfer the Actinomadura pusilla group to the emended genus Microtetraspora. However, they did not include the type strain of $A$. carminata in their study. Kroppenstedt \& Goodfellow (1992) and 
Goodfellow (1992) comprehensively reviewed the taxonomy of the families Thermomonosporaceae and Streptosporangiaceae. Miyadoh et al. (1997) showed the morphological diversity in these families in the Atlas of Actinomycetes. Zhang et al. (1998) established the genus Nonomuria, on the basis of $16 \mathrm{~S}$ rDNA sequence analysis, and transferred the Microtetraspora pusilla group to the new taxon. Chiba et al. (1999) later corrected the genus name from Nonomuria to Nonomuraea to conform with the rules of the International Code of Nomenclature of Bacteria.

In the present paper, the taxonomic position of strain SF2303 is evaluated by comparing it with two anthracycline-producing type strains; we propose the transfer of $A$. carminata to a new subspecies of the genus Nonomuraea as $N$. roseoviolacea subsp. carminata comb. nov.

\section{METHODS}

Bacterial strains. Strain SF2303 (= IFO 16417 = NRRL B24114) was isolated by the dry heating method developed by Nonomura \& Ohara (1969) from a soil sample collected at Yokohama, Japan, in 1980. The type strains used in this study were obtained from the Japan Collection of Microorganisms (Saitama, Japan) and the Institute for Fermentation (Osaka, Japan).

Morphological, cultural and physiological characteristics. The methods adopted by the International Streptomyces Project (Shirling \& Gottlieb, 1966) were used for morphological, cultural and physiological characterization. Observations were made after incubation at $28{ }^{\circ} \mathrm{C}$ for $2-4$ weeks. Colour determinations were made by comparing the cultures with colour chips from the Color Harmony Manual, 4th edn (1958). For scanning electron microscopy, a sporebearing agar block was fixed overnight in osmium tetroxide fumes, frozen in liquid nitrogen and then freeze-dried. Each specimen was coated with gold-palladium by using an ionsputter instrument and was then observed with a scanning electron microscope (model JSM6300F; Japan Electron Optics Laboratory).

Chemical analysis of cells. Cell walls were prepared by disrupting about $1-2 \mathrm{~g}$ freeze-dried cells with glass beads $(0.1 \mathrm{~mm}$ in diameter) by using a sonic oscillator (model Insonator $201 \mathrm{M}$; Kubota) at $180 \mathrm{~W}$ for $30 \mathrm{~min}$. Nondisrupted cells were removed by centrifugation at $3000 \mathrm{~g}$ for $30 \mathrm{~min}$ and then a crude wall fraction was recovered from the supernatants at 18000 r.p.m. $(26000 \mathrm{~g})$ for $30 \mathrm{~min}$. The pellets were suspended in $4 \%$ SDS solution and boiled for 40 min. Cell walls were collected by spinning at 18000 r.p.m. for $30 \mathrm{~min}$ at $25^{\circ} \mathrm{C}$, washed twice with purified water at $25^{\circ} \mathrm{C}$ and then freeze-dried. The presence of amino acids and sugars in cell wall and whole-cell hydrolysates was determined by the methods of Becker et al. (1965) and Lechevalier (1968). The ratio of diaminopimelic acid stereoisomers was determined by using 2,3,4,6-tetra- $O$-acetyl$\beta$-D-glucopyranosyl isothiocyanate as a chiral reagent (Takahashi et al., 1989). Phospholipids were analysed by the procedure of Lechevalier \& Lechevalier (1970). Menaquinone samples were prepared by extraction with chloroform/methanol (2:1) from freeze-dried cells and subsequent purification by TLC. They were analysed by using a reverse-phase HPLC-mass spectrometer (models HP1090 and HP5989A with an interface of particle beam-
EI; Hewlett Packard). Cellular fatty acids extracted with $n$ hexane were transformed to methyl ester derivatives with anhydrous methanolic $\mathrm{HCl}$ and were analysed by using a GLC-mass spectrometer (models HP5890 and HP5989A; Hewlett Packard).

Fermentation, extraction and analysis of secondary metabolites. The method for fermentation, extraction and analysis of secondary metabolites, including anthracycline antibiotics, was as follows. Well-grown slant cultures of strain SF2303, A. carminata IFO $15903^{\mathrm{T}}$ and $N$. roseoviolacea IFO $14098^{\mathrm{T}}$ were used to inoculate $20 \mathrm{ml}$ of a seed medium consisting of soluble starch $(2.0 \%)$, glucose $(1.0 \%)$, wheat germ $(0.6 \%)$, peptone $(0.5 \%)$, yeast extract $(0.3 \%)$, soybean meal $(0 \cdot 2 \%)$ and $\mathrm{CaCO}_{3}(0 \cdot 1 \%)(\mathrm{pH} 7 \cdot 0)$ in $100 \mathrm{ml}$ Erlenmeyer flasks. The flasks were shaken at $28^{\circ} \mathrm{C}$ for $3 \mathrm{~d}$ on a rotary shaker (220 r.p.m.) and then transferred into $80 \mathrm{ml}$ production medium consisting of maltose syrup $(3.0 \%)$, soybean meal $(1.0 \%)$, soluble vegetable protein $(0.5 \%)$, wheat germ $(0.5 \%)$ and $\mathrm{CaCO}_{3}(0 \cdot 1 \%)(\mathrm{pH} 7 \cdot 0)$ in $500 \mathrm{ml}$ Erlenmeyer flasks. The flasks were shaken at $28^{\circ} \mathrm{C}$ for $5 \mathrm{~d}$. After fermentation, $80 \mathrm{ml}$ acetone was added to each flask; the flasks were shaken violently before removal of the mycelial mass by centrifugation. These acetone extracts were analysed by using an HPLC-mass spectrometer (models HP1090L and HP5989A; Hewlett Packard).

Preparation of DNA. Total DNA was isolated from cells grown in yeast extract/glucose broth according to the method of Saito \& Miura (1963), with modifications. Wet biomass (approx. $3 \mathrm{~g}$ ) was suspended in $10 \mathrm{ml}$ TE buffer (10 mM Tris/HCl, $1 \mathrm{mM}$ EDTA; pH 8.0) supplemented with lysozyme $\left(10 \mathrm{mg} \mathrm{ml}^{-1}\right)$ and incubated for $15 \mathrm{~min}$ at $37^{\circ} \mathrm{C}$ before the addition of $1 \mathrm{ml} 20 \%(\mathrm{w} / \mathrm{v}) \mathrm{SDS}, 10 \mathrm{ml}$ Tris/ $\mathrm{HCl}(\mathrm{pH} \mathrm{8.0)}$-saturated phenol and $1.5 \mathrm{ml} 5 \mathrm{M} \mathrm{NaCl}$. The resulting preparation was centrifuged at $5000 \mathrm{~g}$ for $10 \mathrm{~min}$, the supernatant was extracted twice with equal volumes of chloroform and the crude DNA precipitate was recovered with an equal volume of 2-propanol. The DNA was resuspended in $10 \mathrm{ml} \mathrm{TE}$ buffer and incubated first with RNase A (20 $\mu \mathrm{g} \mathrm{m}^{-1}$; Sigma) for $60 \mathrm{~min}$ at $50{ }^{\circ} \mathrm{C}$ and then with proteinase $\mathrm{K}(100 \mu \mathrm{g} \mathrm{ml})^{-1}$; Sigma ) for $60 \mathrm{~min}$ at $37^{\circ} \mathrm{C}$. Thereafter, the DNA was extracted once with phenol and twice with chloroform. It was then precipitated with 2propanol. The precipitate was rinsed with $70 \%$ ethanol, dried and then dissolved in TE buffer. The concentration and quality of each DNA preparation were determined by using a spectrophotometer (model DU 68; Beckman).

16S rDNA sequence analysis. The $16 \mathrm{~S}$ rDNA was amplified by using the PCR method with Taq DNA polymerase (Takara) and a pair of primers (5'-GAGTTTGATCCTGGCTCAG-3' and 5'-AAGGAGGTGATCCAGCC-3', positions 9-27 and 1541-1525 according to Escherichia coli numbering). The conditions for thermal cycling were as follows: denaturation of the target DNA at $96^{\circ} \mathrm{C}$ for $2 \mathrm{~min}$ followed by 30 cycles of denaturation at $95^{\circ} \mathrm{C}$ for $40 \mathrm{~s}$, primer annealing at $53{ }^{\circ} \mathrm{C}$ for $1 \mathrm{~min}$ and primer extension at $72{ }^{\circ} \mathrm{C}$ for $2 \mathrm{~min}$. At the end of the cycling, the reaction mixture was held at $72{ }^{\circ} \mathrm{C}$ for $5 \mathrm{~min}$ and then cooled to $4{ }^{\circ} \mathrm{C}$.

The $1.5 \mathrm{~kb}$ amplified $16 \mathrm{~S}$ rDNA was subjected to cycle sequencing with a dRhodamine terminator cycle sequencing kit (PE Applied Biosystems), according to the manufacturer's protocol, with the following primers: 5'-GAGTTTGATCCTGGCTCAG-3' (9-17), 5'-CTCCTACGGGAGGCAGCAG-3' (339-357), 5'-GTATTACCGCGGCTGCTG-3' (536-519), 5'-GCAACGAGCGCAACCC-3' (10991114), 5'-GCGGTGTGTACAAGGCCC-3' (1382-1365) 

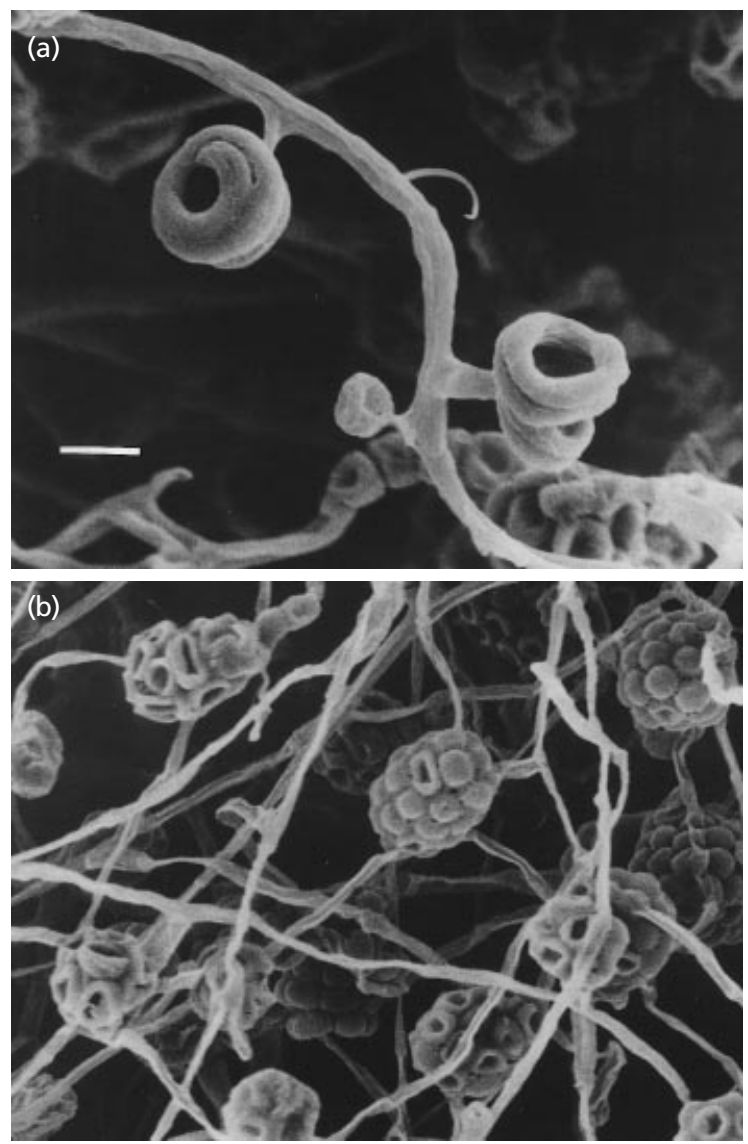

Fig. 1. Scanning electron micrographs of Actinomadura carminata IFO $15903^{\top}$ on humic acid-vitamin agar (Hayakawa \& Nonomura, 1987) after incubation at $28{ }^{\circ} \mathrm{C}$ for $5 \mathrm{~d}$ (a) and for 2 weeks (b). Bar, $1.0 \mu \mathrm{m}$.

and 5'-GGCTACCTTGTTACGACTT-3' (1492-1474). Thermal cycling was performed as follows: denaturation of the target DNA at $96^{\circ} \mathrm{C}$ for $30 \mathrm{~s}$ followed by 25 cycles of denaturation at $96^{\circ} \mathrm{C}$ for $30 \mathrm{~s}$, primer annealing at $50^{\circ} \mathrm{C}$ for $15 \mathrm{~s}$ and primer extension at $60^{\circ} \mathrm{C}$ for $4 \mathrm{~min}$. The products were analysed with a DNA sequencer (ABI PRISM model 377 ) according to the manufacturer's protocol.

Phylogenetic analysis. The 16S rDNA sequences of the strains and reference organisms were aligned against that of
Streptomyces ambofaciens (Pernodet et al., 1989). The CLUSTAL W software package version 1.6 (Thompson et al., 1994) was used to generate evolutionary distances (the $K_{\text {nuc }}$ value of Kimura, 1980) and similarity values; the phylogenetic tree was constructed by the neighbour-joining method (Saitou \& Nei, 1987) from $K_{\text {nuc }}$ values. The topology of the phylogenetic tree was evaluated by the bootstrap resampling method of Felsenstein (1985) with 1000 replicates.

DNA-DNA hybridization. DNA probes (10-20 ng purified DNA per labelling reaction) were radiolabelled with $[\alpha-$

$\left.{ }^{32} \mathrm{P}\right] \mathrm{dCTP}$ (Redivue; Amersham Pharmacia Biotech) using a random prime DNA-labelling system (Rediprime II; Amersham Pharmacia Biotech). Hybridizations were done on nylon membranes (Hybond-N + ; Amersham Pharmacia Biotech) according to the dot-blotting protocol of the supplier. Unlabelled target DNAs $(1.0 \mu \mathrm{g})$ were spotted onto a membrane, denatured with $0.4 \mathrm{M} \mathrm{NaOH}$ for $15 \mathrm{~min}$ and then neutralized and fixed to the membrane with $1.5 \mathrm{M}$ $\mathrm{NaCl} / 0 \cdot 5 \mathrm{M}$ Tris (pH 7.5) for $2 \mathrm{~min}$. The blotted membranes were prehybridized with $10 \mathrm{ml}$ hybridization solution $(3 \times$ SSC $/ 0 \cdot 1 \%$ SDS containing denatured non-homologous DNA from calf thymus at a final concentration of $100 \mu \mathrm{g} \mathrm{ml}^{-1}$ and $4 \times$ Denhardt's solution) in a plastic bag at $70{ }^{\circ} \mathrm{C}$ for $1 \mathrm{~h}$ as a prehybridization. Heat-denatured probe was then added to the bag. The reassociation reaction between the membrane-fixed DNA and ${ }^{32} \mathrm{P}$-labelled DNA was performed at $70{ }^{\circ} \mathrm{C}$ for $16-20 \mathrm{~h}$. After hybridization, the membranes were washed twice with $2 \times$ SSC $/ 0 \cdot 1 \%$ SDS for $10 \mathrm{~min}$ at room temperature and once each with $1 \times$ $\mathrm{SSC} / 0 \cdot 1 \% \mathrm{SDS}$ for $10 \mathrm{~min}$ at $70{ }^{\circ} \mathrm{C}$ and $0 \cdot 1 \times \mathrm{SSC} / 0 \cdot 1 \%$ SDS for $10 \mathrm{~min}$ at $70^{\circ} \mathrm{C}$. The membranes were then airdried. The radioactivity of each individual dot was measured using a Fujix bio-imaging analyser (model BAS3000 II; Fuji Photo Film). Hybridization experiments were performed in triplicate.

\section{RESULTS AND DISCUSSION}

\section{Morphological characteristics}

The morphological characteristics of strain SF2303, A. carminata IFO $15903^{\mathrm{T}}$ and $N$. roseoviolacea IFO $14098^{\mathrm{T}}$ were almost the same. Their substrate hyphae were long, irregularly branched and did not fragment into short elements. The aerial hyphae branched monopodially and were $0 \cdot 3-0.4 \mu \mathrm{m}$ in diameter. The spore chains were formed on the aerial hyphae in tightly closed spirals. As shown in Fig. 1(b), well-

Table 1. Cultural characteristics of $A$. carminata IFO $15903^{\top}$ and related strains

Colour designations taken from the Color Harmony Manual, 4th edn (Chicago: Container Corporation of America, 1958).

\begin{tabular}{|c|c|c|c|c|c|c|}
\hline \multirow[t]{2}{*}{ Medium } & \multicolumn{2}{|c|}{ Strain SF2303 } & \multicolumn{2}{|c|}{ N. roseoviolacea IFO $14098^{\mathrm{T}}$} & \multicolumn{2}{|c|}{ A. carminata IFO $15903^{\mathrm{T}}$} \\
\hline & Reverse colour & Aerial mycelium & Reverse colour & Aerial mycelium & Reverse colour & Aerial mycelium \\
\hline Yeast extract/malt extract agar (ISP no. 2) & Old wine & Abundant alabaster tint & Old wine & Abundant alabaster tint & Old wine & Abundant alabaster tint \\
\hline Oatmeal agar (ISP no. 3) & Rose grey & Moderate shell pink & Rose grey & Moderate shell pink & Apricot & Moderate shell pink \\
\hline Inorganic salts/starch agar (ISP no. 4) & Apricot & Abundant shell pink & Apricot & Moderate shell pink & Apricot & Poor shell pink \\
\hline Glycerol/asparagine agar (ISP no. 5) & Melon yellow & None & Melon yellow & None & Melon yellow & None \\
\hline Peptone/yeast extract agar (ISP no. 6) & Light amber & None & Beaver & None & Beaver & None \\
\hline Tyrosine agar (ISP no. 7) & Light tan & None & Light tan & None & Light tan & None \\
\hline Yeast extract/starch agar & Rose grey & Poor cedar rose & Rose grey & Poor cedar rose & Light fawn & Poor alabaster tint \\
\hline Maltose Bennett agar & Cedar & Abundant flesh pink & Old wine & Abundant flesh pink & Old wine & Abundant flesh pink \\
\hline
\end{tabular}


Table 2. Physiological characteristics of $A$. carminata IFO $15903^{\top}$ and related strains

All strains listed were positive for hydrolysis of starch, utilization of D-glucose, L-arabinose, D-fructose, L-rhamnose and D-galactose, growth at 15 and $42{ }^{\circ} \mathrm{C}$ and tolerance of $3 \%$ $\mathrm{NaCl}$ in yeast extract/starch agar. All strains were negative for coagulation and peptonization of milk, utilization of Dmannitol and raffinose and production of melanoid pigment on tyrosine agar (ISP no. 7).

\begin{tabular}{|lccc|}
\hline $\begin{array}{l}\text { Physiological } \\
\text { property }\end{array}$ & SF2303 & $\begin{array}{c}\text { N. roseoviolacea } \\
\text { IFO 14098 }\end{array}$ & $\begin{array}{c}\text { A. carminata } \\
\text { IFO 15903 }^{\mathbf{T}}\end{array}$ \\
\hline $\begin{array}{l}\text { Liquefaction } \\
\text { of gelatin }\end{array}$ & - & + & - \\
$\begin{array}{l}\text { Reduction } \\
\text { of nitrate }\end{array}$ & + & + & - \\
$\begin{array}{l}\text { Utilization of: } \\
\text { D-Xylose }\end{array}$ & $+/-$ & $+/-$ & + \\
$\begin{array}{l}\text { myo-Inositol } \\
\text { Sucrose }\end{array}$ & - & $+/-$ & - \\
\hline
\end{tabular}

developed spore chains were enveloped in a slimy mass, giving the appearance of sporangia (pseudosporangia). The spores were oval to cylindrical in shape and $0 \cdot 6-1 \cdot 2 \mu \mathrm{m}$ in size, with smooth surfaces (Fig. 1).

\section{Cultural and physiological characteristics}

As summarized in Table 1, the cultural characteristics of the three strains are very similar. On ISP medium 2 , these strains formed wine-red-coloured pigments $(\mathrm{pH}$ indicator) due to the production of anthracycline antibiotics. As shown in Table 2, the physiological characteristics of strain SF2303 and $N$. roseoviolacea strain IFO $14098^{\mathrm{T}}$ were very similar but were different from those of $A$. carminata IFO $15903^{\mathrm{T}}$ in terms of the utilization of sucrose and D-xylose and the reduction of nitrate.

\section{Chemotaxonomic characteristics}

The chemotaxonomic characteristics of strain SF2303, A. carminata IFO $15903^{\mathrm{T}}$ and $N$. roseoviolacea IFO $14098^{\mathrm{T}}$ were basically identical. The cell wall of the strains contained meso-diaminopimelic acid, glutamic acid and alanine, with small amounts of LLdiaminopimelic acid and glycine. As shown in Table 3, the proportion of meso-diaminopimelic acid in the three strains was $71-73 \%$. The proportions in other species of the family Streptosporangiaceae (Herbido-

Table 3. Proportions of diaminopimelic acid stereoisomers in the cell walls of $A$. carminata IFO $15903^{\top}$ and related strains

Proportions were determined as follows: $20 \mu 15 \%(\mathrm{v} / \mathrm{v})$ triethylamine solution and $10 \mu 12 \%$ (v/v) 2,3,4,6-tetra- $O$-acetyl- $\beta$-D-glucopyranosyl isothiocyanate solution in acetonitrile were added to $10 \mu \mathrm{l}$ cell wall hydrolysate in $0 \cdot 1 \mathrm{M} \mathrm{HCl}$. The resulting mixture was allowed to stand at room temperature for $25 \mathrm{~min}$. The derivatization reaction was stopped by the addition of $20 \mu 150 \mathrm{mM}$ aqueous taurine solution. Amino acid derivatives were analysed by using an HPLC-mass spectrometer. $\mathrm{A}_{2} \mathrm{pm}$, Diaminopimelic acid.

\begin{tabular}{|c|c|c|}
\hline Strain & $m e s o-\mathrm{A}_{2} \mathrm{pm}(\%)$ & LL-A $\mathbf{A}_{2} \mathrm{pm}(\%)$ \\
\hline \multicolumn{3}{|l|}{ Family Streptosporangiaceae } \\
\hline Strain SF2303 & 71 & 29 \\
\hline A. carminata IFO $15903^{\mathrm{T}}$ & 71 & 29 \\
\hline N. roseoviolacea $\mathrm{IFO} 15238^{\mathrm{T}}$ & 73 & 27 \\
\hline Herbidospora cretacea JCM 8554 & 75 & 25 \\
\hline Microbispora rosea IFO $14044^{\mathrm{T}}$ & 77 & 23 \\
\hline Microtetraspora glauca IFO $14761^{\mathrm{T}}$ & 75 & 25 \\
\hline Nonomuraea helvata IFO $14681^{\mathrm{T}}$ & 73 & 27 \\
\hline Nonomuraea pusilla IFO $14684^{\mathrm{T}}$ & 76 & 24 \\
\hline Nonomuraea spiralis JCM $3286^{\mathrm{T}}$ & 74 & 26 \\
\hline Streptosporangium roseum $\mathrm{IFO} 3776^{\mathrm{T}}$ & 71 & 29 \\
\hline \multicolumn{3}{|l|}{ Family Thermomonosporaceae } \\
\hline Actinomadura citrea IFO $14678^{\mathrm{T}}$ & 83 & 17 \\
\hline Actinomadura kijaniata IFO $14229^{\mathrm{T}}$ & 87 & 13 \\
\hline Actinomadura madurae IFO $14623^{\mathrm{T}}$ & 80 & 20 \\
\hline Actinomadura viridis IFO $15238^{\mathrm{T}}$ & 88 & 12 \\
\hline \multicolumn{3}{|l|}{ Others } \\
\hline Streptomyces griseus IFO $12875^{\mathrm{T}}$ & 0 & 100 \\
\hline Rhodococcus erythropolis JCM 3011 & 100 & 0 \\
\hline
\end{tabular}


Table 4. Cellular fatty acid composition of $A$. carminata IFO $15903^{\top}$ and related strains

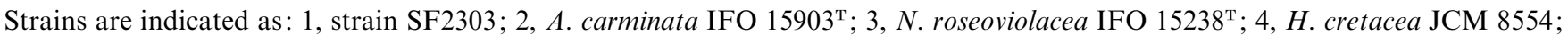
5 , Microbispora rosea IFO $14044^{\mathrm{T}} ; 6$, Microtetraspora glauca IFO $14761^{\mathrm{T}} ; 7$, Nonomuraea ferruginea IFO $14094^{\mathrm{T}} ; 8, N$. helvata IFO $14681^{\mathrm{T}} ; 9, N$. pusilla IFO $14684^{\mathrm{T}} ; 10, N$. spiralis JCM $3286^{\mathrm{T}} ; 11$, Streptosporangium roseum IFO $3776^{\mathrm{T}} ; 12$, A. citrea IFO $14678^{\mathrm{T}}$; 13, Actinomadura coerulea IFO 14679 $; 14$, A. kijaniata IFO 14229 ${ }^{\mathrm{T}}$; 15, Actinomadura luteofluorescens JCM 4203 ${ }^{\mathrm{T}}$; 16, A. madurae IFO $14623^{\mathrm{T}}$; 17, Actinomadura vinacea JCM $3325^{\mathrm{T}}$; and 18 , A. viridis IFO $15238^{\mathrm{T}}$. Fatty acid abbreviations are shown according to the following example: iso-16:0, 14-methylpentadecanoic acid; 10M-18:0, 10-methyloctadecanoic acid (tuberculostearic acid); 18:1, oleic acid.

\begin{tabular}{|c|c|c|c|c|c|c|c|c|c|c|c|c|c|c|c|c|c|c|}
\hline \multirow[t]{2}{*}{ Fatty acid } & \multicolumn{11}{|c|}{ Family Streptosporangiaceae } & \multicolumn{7}{|c|}{ Family Thermomonosporaceae } \\
\hline & 1 & 2 & 3 & 4 & 5 & 6 & 7 & 8 & 9 & 10 & 11 & 12 & 13 & 14 & 15 & 16 & 17 & 18 \\
\hline $14: 0$ & - & - & - & 4 & 2 & 2 & - & 5 & 2 & - & - & - & - & - & - & 2 & 1 & - \\
\hline $15: 0$ & 4 & 7 & 10 & 13 & 3 & 6 & 3 & 3 & 5 & 7 & 9 & - & 1 & 1 & 1 & 2 & 4 & - \\
\hline $16: 0$ & 7 & 5 & 6 & 8 & 15 & 6 & 3 & 17 & 5 & 2 & 5 & 39 & 44 & 36 & 38 & 33 & 37 & 28 \\
\hline $17: 0$ & 11 & 15 & 12 & 8 & 2 & 2 & 6 & 2 & 3 & 5 & 8 & - & 1 & 2 & 1 & 3 & 8 & - \\
\hline $18: 0$ & - & - & - & - & - & - & - & - & - & - & - & 5 & 5 & 19 & 4 & 8 & 10 & 11 \\
\hline iso- $14: 0$ & - & - & - & 4 & 2 & 2 & 2 & - & 1 & 4 & 7 & - & - & - & - & - & 1 & - \\
\hline iso- $15: 0$ & 5 & 3 & 3 & 2 & 3 & 3 & - & 4 & 3 & 2 & 1 & - & - & - & - & - & - & - \\
\hline iso-16:0 & 19 & 25 & 18 & 8 & 23 & 21 & 18 & 7 & 20 & 40 & 8 & 1 & 9 & 2 & 2 & 8 & 4 & 11 \\
\hline $16: 1$ & 1 & 3 & 1 & 3 & 15 & 5 & 3 & 22 & 3 & - & 2 & 11 & 4 & 2 & 21 & 2 & 8 & 6 \\
\hline $17: 1$ & 5 & 4 & 5 & 18 & 5 & 12 & 26 & 10 & 10 & 3 & 19 & - & - & - & - & - & 2 & - \\
\hline $18: 1$ & - & 1 & - & 2 & 3 & 3 & 5 & 6 & 2 & - & 3 & 27 & 11 & 22 & 18 & 23 & 14 & 18 \\
\hline iso- $16: 1$ & - & - & - & - & - & 3 & 1 & - & 2 & 2 & - & - & - & - & - & - & - & - \\
\hline iso- $18: 1$ & - & - & - & - & - & 2 & 4 & - & 4 & 1 & - & - & - & - & - & 1 & - & 1 \\
\hline $10 \mathrm{M}-16: 0$ & 6 & 4 & 5 & - & 9 & 4 & - & 6 & 4 & 1 & 2 & - & 2 & - & 2 & - & 2 & - \\
\hline $10 \mathrm{M}-17: 0$ & 24 & 20 & 27 & 6 & 3 & 9 & 6 & 2 & 11 & 14 & 15 & - & 2 & - & - & - & - & - \\
\hline $10 \mathrm{M}-18: 0$ & 4 & 5 & 5 & - & 1 & 1 & - & 1 & 2 & - & 2 & 16 & 14 & 14 & 10 & 13 & 7 & 18 \\
\hline $2 \mathrm{OH}$-iso- $16: 0$ & 7 & 3 & 3 & 5 & 8 & 11 & 15 & 3 & 13 & 14 & 5 & - & - & - & - & - & - & - \\
\hline $2 \mathrm{OH}-15: 0$ & - & - & - & 4 & - & 2 & - & 1 & 2 & 3 & 3 & - & - & - & - & - & - & - \\
\hline $2 \mathrm{OH}-16: 0$ & 3 & 2 & 2 & 6 & 3 & 4 & 3 & 8 & 3 & - & 5 & - & - & - & - & - & - & - \\
\hline
\end{tabular}
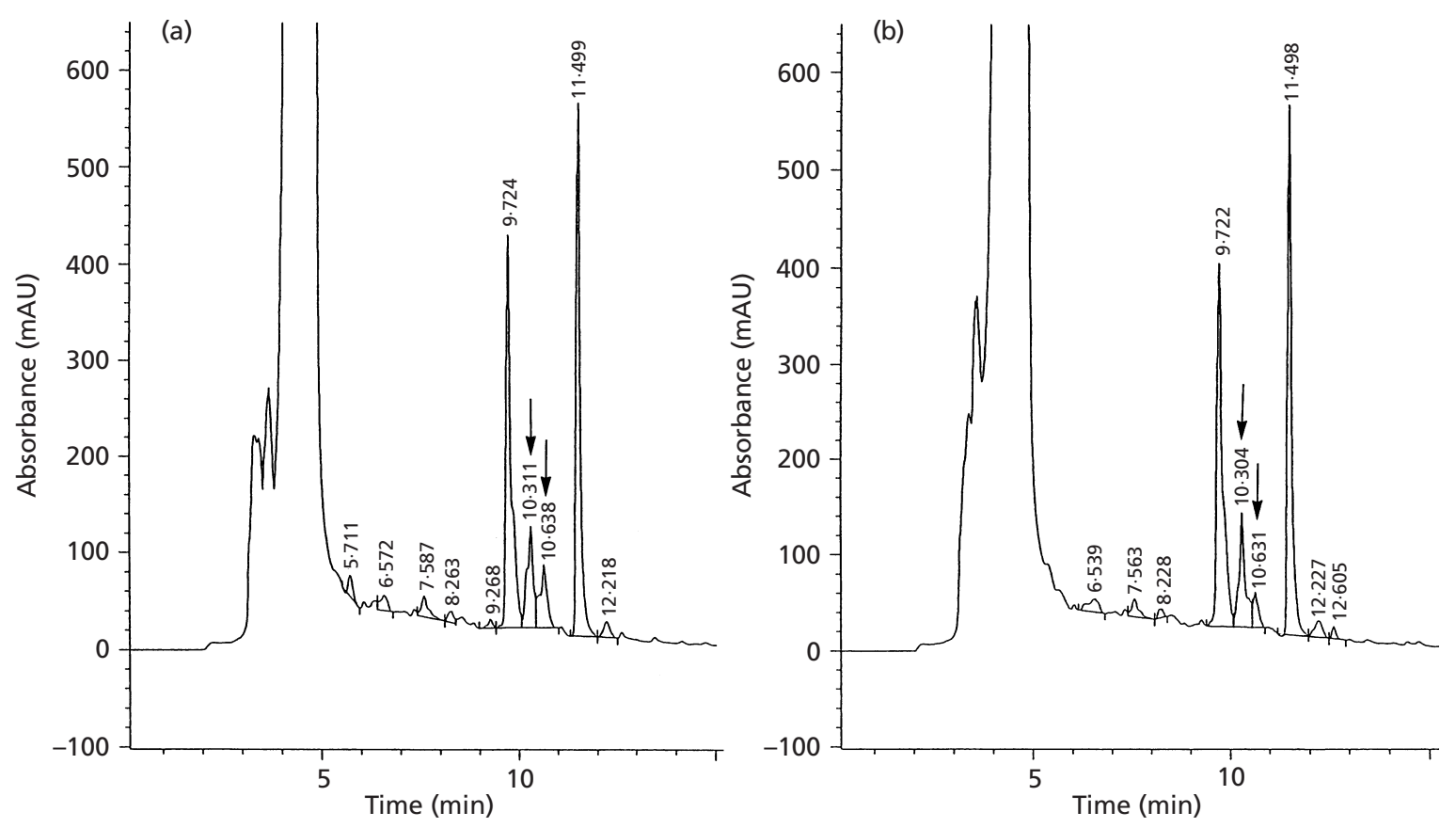

Fig. 2. HPLC patterns of secondary metabolites, including anthracyclines. Arrows indicate anthracycline peaks. (a) $A$. carminata IFO $15903^{\top}$; (b) N. roseoviolacea IFO $14098^{\top}$. 


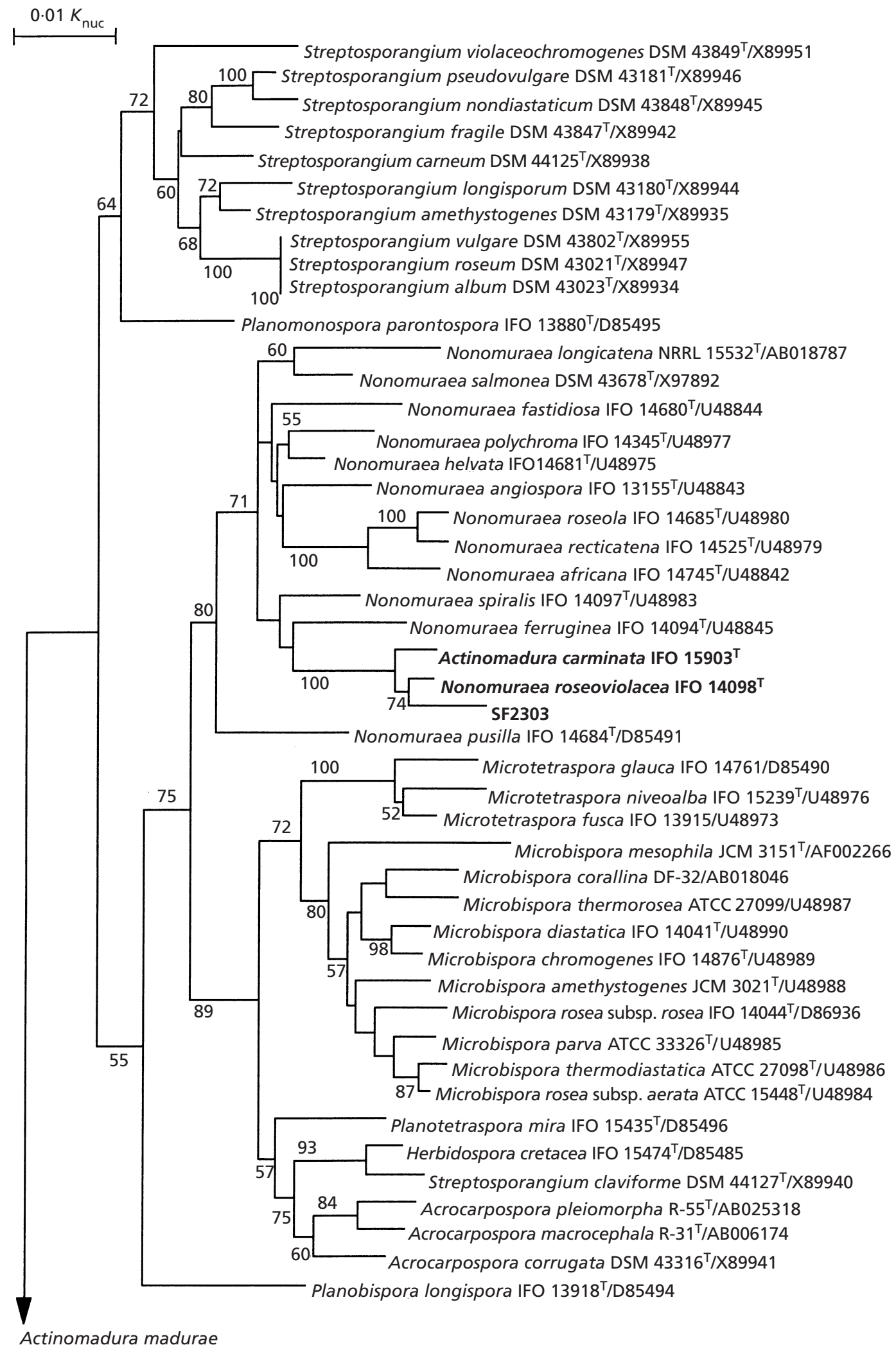

Fig. 3. Phylogenetic tree of the family Streptosporangiaceae, including A. carminata IFO $15903^{\top}$ and related strains, based on $16 \mathrm{~S}$ rDNA sequence analysis by the neighbour-joining method. The accession numbers for the sequences used for reference are given after the strain numbers. Actinomadura madurae (D85468) and Streptomyces ambofaciens (M27245) were used as the root organisms. Bar, 0.01 $K_{\text {nuc }}$ 
Table 5. DNA relatedness of $A$. carminata IFO $15903^{\top}$ and related strains

\begin{tabular}{|c|c|c|c|c|c|c|}
\hline \multirow[t]{2}{*}{ Source of unlabelled DNA } & \multicolumn{6}{|c|}{ Hybridization (\%) with ${ }^{32} \mathrm{P}$-labelled DNA from: } \\
\hline & 1 & 2 & 3 & 4 & 5 & 6 \\
\hline 1. Strain SF2303 & 100 & 60 & 71 & 11 & 19 & 6 \\
\hline 2. A. carminata IFO $15903^{\mathrm{T}}$ & 54 & 100 & 49 & 9 & 12 & 7 \\
\hline 3. $N$. roseoviolacea IFO $14098^{\mathrm{T}}$ & 78 & 52 & 100 & 11 & 12 & 7 \\
\hline 4. N. helvata IFO $14681^{\mathrm{T}}$ & 24 & 18 & 10 & 100 & 21 & 7 \\
\hline 5. Nonomuraea roseola IFO $14685^{\mathrm{T}}$ & 20 & 15 & 13 & 9 & 100 & 6 \\
\hline 6. Nonomuraea fastidiosa IFO $14680^{\mathrm{T}}$ & 9 & 16 & 6 & 5 & 14 & 2 \\
\hline 7. Streptomyces griseus IFO $12875^{\mathrm{T}}$ & 20 & 8 & 10 & 3 & 5 & 100 \\
\hline
\end{tabular}

spora cretacea, Microbispora rosea, Microtetraspora glauca, three Nonomuraea species and Streptosporangium roseum) and in the four Actinomadura species were $71-77 \%$ and $80-88 \%$, respectively. Whole-cell hydrolysates of the three strains contained glucose, mannose, galactose, ribose and madurose. These data indicate that they have a type III cell wall and a type B whole-cell sugar pattern. In the process of these analyses, we reconfirmed that the cell wall of $A$. carminata IFO $15903^{\mathrm{T}}$ contained non-peptidoglycan amino acids, as reported by Naumova et al. (1986). These authors reported that these amino acids were a specific cell wall component of this strain only and were removed completely from the wall by trypsin digestion. However, we found that this phenomenon was common in all of the genera belonging to the family Streptosporangiaceae. This characteristic might be a new chemotaxonomic marker for actinomycetes, and we are planning to report the data elsewhere. The major menaquinone was MK-9 $\left(\mathrm{H}_{4}\right)$, with saturated isoprene units at sites III and VIII. This saturation pattern of isoprenoids is characteristic of the family Streptosporangiaceae, as reported by Kroppenstedt et al. (1990). Strain SF2303, A. carminata IFO 15903 and $N$. roseoviolacea IFO $14098^{\mathrm{T}}$ contained both glucosamine-containing phospholipid and phosphatidylethanolamine as cellular phospholipids (a type PIV phospholipid pattern; Lechevalier et al., 1981). As shown in Table 4, the cellular fatty acids of members of the family Streptosporangiaceae, represented by three strains, were very complex and were characterized by the presence of 17:1/10M-17:0 (10-methylheptadecanoic acid) and 2-hydroxy fatty acids. In contrast, the cellular fatty acid profiles of strains of the Thermomonosporaceae were relatively simple, containing 16:0 (palmitic acid) and 18:1 (oleic acid)/10M-18:0 (tuberculostearic acid) as major fatty acids. Lennarz et al. (1962) demonstrated that 18:1 fatty acid was the precursor of 10M-18:0 fatty acid in Mycobacterium phlei. Suzuki \& Komagata (1983) noted an increase in methylation as cultures aged. Mycolic acids were not detected. The acyl type of the cell wall peptidoglycan was the acetyl type. These chemotaxonomic characteristics of the three strains were identical to those of the family Streptosporangiaceae. Therefore, $A$. carminata IFO $15903^{\mathrm{T}}$ should be transferred from the genus Actinomadura, belonging to the family Thermomonosporaceae, to the family Streptosporangiaceae. As shown in Fig. 2, HPLC analysis revealed that the secondary metabolites, including anthracyclines, of $A$. carminata IFO $15903^{\mathrm{T}}$ were essentially identical to those of $N$. roseoviolacea IFO $14098^{\mathrm{T}}$. This result strongly supported the above conclusion.

\section{S rDNA sequence analysis}

Fig. 3 shows a neighbour-joining phylogenetic tree of type strains of the family Streptosporangiaceae, including strain SF2303 and strains that are related on the basis of $16 \mathrm{~S}$ rDNA sequences. The three strains fell into the genus Nonomuraea cluster. Thus, in phylogenetic terms, A. carminata IFO $15903^{\mathrm{T}}$ does not to belong to the genus Actinomadura.

\section{DNA-DNA hybridization}

The results of DNA-DNA hybridization among these three strains, the other three type strains of the genus Nonomuraea and Streptomyces griseus IFO $12875^{\mathrm{T}}$ are shown in Table 5. The levels of DNA relatedness between strain SF2303 and $N$. roseoviolacea IFO $14098^{\mathrm{T}}$ ranged from 71 to $78 \%$; however, the levels between these two strains and $A$. carminata IFO $15903^{\mathrm{T}}$ were lower $(49-60 \%)$. In contrast, low levels $(2-24 \%)$ of relatedness were found between these three strains and the other four strains. Therefore, we identified strain SF2303 (IFO 16417) as a member of the species Nonomuraea roseoviolacea, and we propose the transfer of $A$. carminata Gauze et al. 1973 to a new subspecies of genus Nonomuraea Zhang et al. 1998 as $N$. roseoviolacea subsp. carminata comb. nov.

\section{Description of Nonomuraea roseoviolacea subsp. carminata (Gauze et al. 1973) comb. nov.}

Basonym Actinomadura carminata Gauze et al. 1973. Substrate hyphae are long, irregularly branched and do not fragment into short elements. Aerial hyphae branch monopodially and are $0.3-0.4 \mu \mathrm{m}$ in diameter. Spore chains are formed on the aerial hyphae in tightly 
closed spirals. Well-developed spore chains are enveloped in a slimy mass, giving the appearance of sporangia (pseudosporangia). Spores are oval to cylindrical in shape and $0.6-1.2 \mu \mathrm{m}$ in size, with smooth surfaces. The colour of the aerial hyphal mass is pink, and a wine-red soluble colour is formed in ISP medium 2. Zoospores are not formed. Hydrolysis of starch and growth at $42{ }^{\circ} \mathrm{C}$ are positive. Reduction of nitrate, liquefaction of gelatin, peptonization of milk and production of melanoid pigment are negative. Grows in the presence of $3 \% \mathrm{NaCl}$. Utilizes D-glucose, Larabinose, D-xylose, D-fructose, L-rhamnose, sucrose and D-galactose, but not myo-inositol, D-mannitol or raffinose. Cell wall chemotype IIIB. Phospholipid type PIV. MK-9 (III, VIII-H ${ }_{4}$ ) is the major menaquinone. Cellular fatty acids are characterized by the presence of $10 \mathrm{M}-17: 0 / 17: 1$ and iso-16:0 as major components and 2-hydroxy fatty acids as minor components. Mycolic acids are not produced. The cell wall peptidoglycan is of the acetyl type. Aerobic. Mesophilic. Antagonistic properties: produces anthracyclines. The habitat is soil. The type strain is IFO $15903^{\mathrm{T}}(=$ INA $\left.4281^{\mathrm{T}}\right)$.

\section{Description of Nonomuraea roseoviolacea subsp. roseoviolacea (Nonomura and Ohara 1971) Zhang et al. 1998 comb. nov.}

According to Rule 40d (formerly Rule 46) of the International Code of Nomenclature of Bacteria, the valid publication of Nonomuraea roseoviolacea subsp. carminata automatically creates another subspecies, Nonomuraea roseoviolacea subsp. roseoviolacea (Nonomura and Ohara 1971) Zhang et al. 1998.

The original description of Nonomuraea roseoviolacea subsp. roseoviolacea given by Nonomura \& Ohara (1971) is unchanged. In addition, this subspecies is characterized by the following chemotaxonomic properties. Cell wall chemotype IIIB. Phospholipid type PIV. MK-9 (III, VIII-H4) is the major menaquinone. Cellular fatty acids are characterized by the presence of $10 \mathrm{M}-17: 0 / 17: 1$ and iso-16:0 as major components and 2-hydroxy fatty acids as minor components. Mycolic acids are not produced. The cell wall peptidoglycan is of the acetyl type. The type strain is IFO $14098^{\mathrm{T}}$.

\section{ACKNOWLEDGEMENTS}

We would like to acknowledge Drs Hubert A. Lechevalier and Mary P. Lechevalier for critical review of the manuscript and for their encouragement throughout the work. We wish to thank Dr T. Tamura for help with the study of $16 \mathrm{~S}$ rDNA.

\section{REFERENCES}

Athalye, M., Goodfellow, M. \& Minnikin, D. E. (1984). Menaquinone composition in the classification of Actinomadura and related taxa. J Gen Microbiol 130, 817-823.

Becker, B., Lechevalier, M. P. \& Lechevalier, H. (1965). Chemical composition of cell-wall preparations from strains of various form-genera of aerobic actinomycetes. Appl Microbiol 13, 236-243.

Chiba, S., Suzuki, M. \& Ando, K. (1999). Taxonomic re-evaluation of 'Nocardiopsis' sp. K-252 ( = NRRL 15532 $)$ : a proposal to transfer this strain to the genus Nonomuraea as Nonomuraea longicatena sp. nov. Int J Syst Bacteriol 49, 1623-1630.

Felsenstein, J. (1985). Confidence limits on phylogenies: an approach using the bootstrap. Evolution 39, 783-791.

Fischer, A., Kroppenstedt, R. M. \& Stackebrandt, E. (1983). Molecular-genetic and chemotaxonomic studies on Actinomadura and Nocardiopsis. J Gen Microbiol 129, 3433-3446.

Gauze, G. F., Sveshnikova, M. A., Ukholina, R. S., Gavrilina, G. N. \& Filicheva, V. A. (1973). Production of antineoplastic antibiotic carminomycin by Actinomadura carminata sp. nov. Antibiotiki 18, 675-678 (in Russian).

Goodfellow, M. (1992). The family Streptosporangiaceae. In The Prokaryotes, 2nd edn, vol. 2, pp. 1115-1138. Edited by A. Balows, H. G. Trüper, M. Dworkin, W. Harder \& K.-H. Schleifer. New York: Springer.

Grund, E. \& Kroppenstedt, R. M. (1989). Transfer of five Nocardiopsis species to the genus Saccharothrix Labeda et al. 1984. Syst Appl Microbiol 12, 267-274.

Hayakawa, M. \& Nonomura, H. (1987). Humic acid-vitamin agar, a new medium for the selective isolation of soil actinomycetes. J Ferment Technol 65, 501-509.

Kimura, M. (1980). A simple method for estimating evolutionary rates of base substitutions through comparative studies of nucleotide sequences. $J$ Mol Evol 16, 111-120.

Kroppenstedt, R. M. \& Goodfellow, M. (1992). The family Thermomonosporaceae. In The Prokaryotes, 2nd edn, vol. 2, pp. 1085-1114. Edited by A. Balows, H. G. Trüper, M. Dworkin, W. Harder \& K.-H. Schleifer. New York: Springer.

Kroppenstedt, R. M., Stackebrandt, E. \& Goodfellow, M. (1990). Taxonomic revision of the actinomycete genera Actinomadura and Microtetraspora. Syst Appl Microbiol 13, 148-160.

Lechevalier, M. P. (1968). Identification of aerobic actinomycetes of clinical importance. J Lab Clin Med 71, 934-944.

Lechevalier, H. A. \& Lechevalier, M. P. (1970). A critical evaluation of the genera of aerobic actinomycetes. In The Actinomycetales, pp. 393-405. Edited by H. Prauser. Jena: Gustav Fischer.

Lechevalier, M. P., Stern, A. E. \& Lechevalier, H. A. (1981). Phospholipids in the taxonomy of actinomycetes. Zentbl Bakteriol Parasitenkd Infektionskr Hyg Abt 1 Suppl 11, 111-116.

Lennarz, W. J., Scheuerbrandt, G. \& Bloch, K. (1962). The biosynthesis of oleic and 10-methylstearic acids in Mycobacterium phlei. J Biol Chem 237, 664-671.

Miyadoh, S., Anzai, H., Amano, S. \& Shomura, T. (1989). Actinomadura malachitica and Microtetraspora viridis are synonyms and should be transferred as Actinomadura viridis comb. nov. Int J Syst Bacteriol 39, 152-158.

Miyadoh, S., Amano, S., Tohyama, H. \& Shomura, T. (1990). A taxonomic review of the genus Microbispora and a proposal to transfer two species to the genus Actinomadura and to combine ten species into Microbispora rosea. J Gen Microbiol 136, 1905-1913.

Miyadoh, S., Hamada, M., Hotta, K., Kudo, T., Seino, A., Vobis, G. \& Yokota, A. (1997). Atlas of Actinomycetes. Tokyo: The Society for Actinomycetes.

Naumova, I. B., Potekhina, N. V., Duigimbaye, C., Shashkov, A. S., Terekhova, L. P. \& Preobrazhenskaya, T. P. (1986). Cell wall 
polymers of Actinomadura carminata INA 4281. Arch Microbiol 146, 256-262.

Nonomura, H. \& Ohara, Y. (1969). Distribution of actinomycetes in soil. VI. A culture method effective for both preferential isolation and enumeration of Microbispora and Streptosporangium strains in soil. J Ferment Technol 47, 463-469.

Nonomura, H. \& Ohara, Y. (1971). Distribution of actinomycetes in soil. XI. Some new species of the genus Actinomadura Lechevalier et al. J Ferment Technol 49, 904-912.

Pernodet, J. L., Boccard, F., Alegre, M. T., Gagnat, J. \& Guérineau, M. (1989). Organization and nucleotide sequence analysis of a ribosomal RNA gene cluster from Streptomyces ambofaciens. Gene 79, 33-46.

Poschner, J., Kroppenstedt, R. M., Fischer, A. \& Stackebrandt, E. (1985). DNA-DNA reassociation and chemotaxonomic studies on Actinomadura, Microbispora, Microtetraspora, Micropolyspora and Nocardiopsis. Syst Appl Microbiol 6, 264-270.

Saito, H. \& Miura, K. (1963). Preparation of transforming deoxyribonucleic acid by phenol treatment. Biochim Biophys Acta 72, 619-629.
Saitou, N. \& Nei, M. (1987). The neighbor-joining method: a new method for reconstructing phylogenetic trees. Mol Biol Evol 4, 406-425.

Shirling, E. B. \& Gottlieb, D. (1966). Methods for characterization of Streptomyces species. Int J Syst Bacteriol 16, 313-340.

Suzuki, K. \& Komagata, K. (1983). Taxonomic significance of cellular fatty acid composition in some coryneform bacteria. Int J Syst Bacteriol 33, 188-200.

Takahashi, Y., Iwai, Y., Tomoda, H., Nimura, N., Kinoshita, T. \& Omura, S. (1989). Optical resolution of 2,6-diaminopimelic acid stereoisomers by high performance liquid chromatography for the chemotaxonomy of actinomycete strains. J Gen Appl Microbiol 35, 27-32.

Thompson, J. D., Higgins, D. G. \& Gibson, T. J. (1994). CLUSTAL $\mathrm{W}$ : improving the sensitivity of progressive multiple sequence alignment through sequence weighting, position-specific gap penalties and weight matrix choice. Nucleic Acids Res 22, 4673-4680.

Zhang, Z., Wang, Y. \& Ruan, J. (1998). Reclassification of Thermomonospora and Microtetraspora. Int J Syst Bacteriol 48, 411-422. 